\title{
Pressure dependence of fluid transport properties of shallow fault systems in the Nankai subduction
} zone

Wataru Tanikawa ${ }^{1 *}$, Hideki Mukoyoshi ${ }^{2,3}$, Weiren Lin $^{1}$, Takehiro Hirose ${ }^{1}$ and Akito Tsutsumi ${ }^{4}$

\begin{abstract}
We measured fluid transport properties at an effective pressure of $40 \mathrm{MPa}$ in core samples of sediments and fault rocks collected by the Integrated Ocean Drilling Program (IODP) NanTroSEIZE drilling project Expedition 316 from the megasplay fault system (site C0004) and the frontal thrust (site C0007) in the Nankai subduction zone. Permeability decreased with effective pressure as a power law function. Permeability values in the fault zones were $8 \times 10^{-18} \mathrm{~m}^{2}$ at site $\mathrm{C0004}$ and $9 \times 10^{-18} \mathrm{~m}^{2}$ at site C0007. Stratigraphic variation in transport properties suggests that the megasplay fault zone may act as a barrier to fluid flow, but the frontal thrust fault zone might not. Depth variation in permeability at site C0007 is probably controlled by the mechanical compaction of sediment. Hydraulic diffusivity at shallow depths was approximately $1 \times 10^{-6} \mathrm{~m}^{2} \mathrm{~s}^{-1}$ in both fault zones, which is small enough to lead to pore pressure generation that can cause dynamic fault weakening. However, absence of a very low permeable zone, which may have formed in the Japan Trench subduction zone, might prevent facilitation of huge shallow slips during Nankai subduction zone earthquakes. Porosity tests under dry conditions might have overestimated the porosity.
\end{abstract}

Keywords: Permeability; Porosity; Integrated Ocean Drilling Program; Expedition 316 (NanTroSEIZE); Hydraulic diffusivity

\section{Findings}

\section{Introduction}

One of the main objectives of the NanTroSEIZE drilling project of the Integrated Ocean Drilling Program (IODP) Expedition 316 was to analyze core samples of active fault zones to investigate dynamic fault processes. There are two potentially active faults at the Nankai margin, the megasplay fault and the frontal thrust (Figure 1). Seismic waveform inversion and numerical analysis results suggest that the megasplay branching fault might have ruptured during the 1944 Tonankai M8.2 tsunamigenic earthquake (Park et al. 2002; Kame et al. 2003; Kikuchi et al. 2003; Park and Kodaira 2012).

Fluid transport properties of fault zones in the Nankai accretionary prism control static hydrologic behavior in the fault zone as well as dynamic fault processes. Historical pore pressure evolution at a depth in the

\footnotetext{
* Correspondence: tanikawa@jamstec.go.jp

'Kochi Institute for Core Sample Research, Japan Agency for Marine-Earth

Science and Technology, Nankoku 783-8502, Japan

Full list of author information is available at the end of the article
}

accretionary prism is related to sediment consolidation and deformation. In addition, pore pressure distribution in fault zones influences fault strength, and a continuous increase in pore pressure can trigger dynamic slip motion (Sibson 1992). When a fault zone is impermeable, a sudden pore pressure rise due to frictional heating or shear compaction during a seismic slip increases fault instability (Lachenbruch 1980; Andrews 2002) and promotes large displacement (Tanikawa and Shimamoto 2009). A low permeable fault zone is also related to the generation of highly pressurized fluid in the megathrust induced by dehydration and fluid influx from oceanic crust (Yoshida and Kato 2011; Kimura et al. 2012; Mitsui et al. 2012). Fluid transport properties in a fault zone also play an important role in the generation of slowslip events and low-frequency earthquakes (Suzuki and Yamashita 2009), which have been observed in the Nankai accretionary prism (Ito and Obara 2006).

The key parameter characterizing fluid flow and transport in media with high porosity is hydraulic diffusivity, which is determined from permeability and specific 


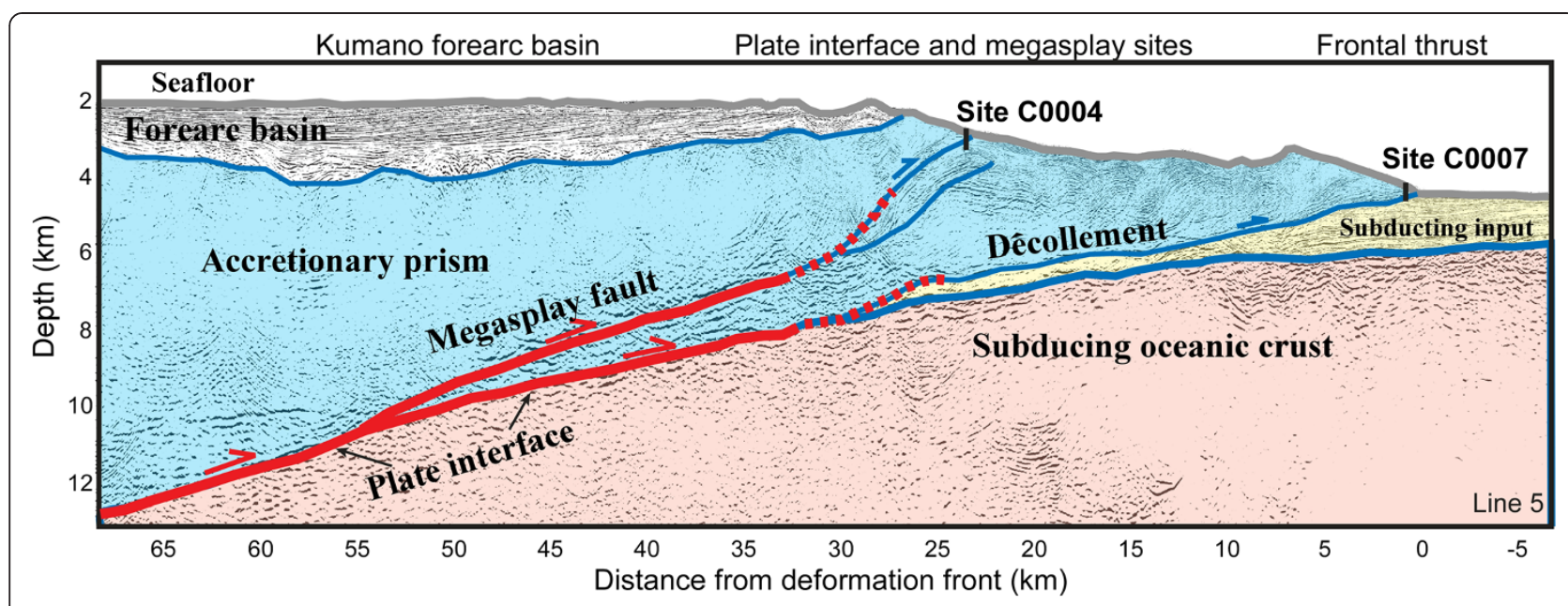

Figure 1 Locations of $\mathrm{C0004}$ and C0007 NanTroSEIZE drilling sites and interpretation of the structure of the Nankai subduction zone.

The seismic reflection section is after Park et al. (2002).

storage measurements. Permeability of sediments and fault rocks is often reported in the literature, but specific storage data are seldom reported. In this study, we measured permeability and specific storage under $40 \mathrm{MPa}$ of confining pressure and less than $1 \mathrm{MPa}$ of pore pressure in core samples from sites C0004 (holes C0004C and C0004D) and C0007 (holes C0007C and C0007D) drilled by IODP Expedition 316. We then estimated the horizontal depth distribution of fluid transport properties in two fault zones in the Nankai accretionary prism.

\section{Samples and experimental settings Fault zone characteristics}

In our laboratory tests, we used core materials from sites C0004 and C0007 (Figure 1) drilled by IODP Expedition 316. Hole C0004D transects the shallow megasplay fault zone, and a major fault zone was identified in this hole at 256 to $315 \mathrm{~m}$ depth below the seafloor (mbsf) within Unit III (Figure 2). The fault zone consists of fractured and brecciated mudstone and volcanic ash (Ujiie et al. 2008), and $10-\mathrm{mm}$-thick shear zones are locally developed in the unit. A large age reversal is found at 307.52 mbsf, which is the boundary between the middle Pliocene Unit III and early Pleistocene Unit IV. In hole C0007D, which penetrates the frontal thrust at the seaward edge of the accretionary wedge, three major fault zones were identified at 237.5 to $259.3,341.5$ to 362.3 , and 398.5 to $446.0 \mathrm{mbsf}$ (Kimura et al. 2008). The latter two fault zones (fault zones 2 and 3 in Figure 2) are located near lithological boundaries. Fault zone 3 is composed of fractured hemipelagic mudstone and ash, fault breccia, and foliated fault gouge. A dark, fine-grained, 2-mm-thick slip layer observed in core section C0007D-29R-2 (438.28 to $438.57 \mathrm{~m}$ ) in fault zone 3 is indicative of high-velocity slip localization during an earthquake (Yamaguchi et al. 2009).

\section{Sample preparation}

We cut cylindrical core samples 20 or $25 \mathrm{~mm}$ in diameter and 6 to $13 \mathrm{~mm}$ in length for the laboratory experiments. However, the amount of available core material limited the size of the samples, and it was difficult to make specimens with the preferred cylindrical shape from fragile rock samples. Therefore, we cut several samples into cuboids with square upper and lower faces, each about 14 to $16 \mathrm{~mm} \times 14$ to $16 \mathrm{~mm}$, and rectangular side faces 7 to 15 $\mathrm{mm}$ long. Most of the core materials from site $\mathrm{C0007}$ are cuboid shaped (Table 1). Matrix volumes and grain densities of the test specimens were measured with a commercial pycnometer (Penta pycnometer, Quantachrome Instruments, Boynton Beach, FL, USA) under atmospheric pressure. Grain densities (Table 1) ranged from 2.6 to $2.71 \mathrm{~g} \mathrm{~cm}^{-3}$. Grain matrix volume data were used for the porosity measurements under high confining pressure.

\section{Experimental procedure}

Both water permeability and porosity were measured at room temperature under uniform (isostatic) confining pressure in a high-pressure oil apparatus at the Kochi Institute for Core Sample Research. Water permeability was measured by the steady-state flow method of Bernabe (1987) with distilled water used as the pore fluid. Before starting permeability tests, samples and pore fluid flow lines were saturated with distilled water by vacuum degassing. The equation for evaluating the (intrinsic) permeability $k_{w}$ is based on Darcy's law and is expressed as

$$
Q=\frac{k_{w} A}{\eta L}\left(P_{u p}-P_{d o w n}\right)
$$

where $Q$ is the volume of fluid measured per unit time, $k_{w}$ is the water permeability, $A$ is the cross-sectional area 


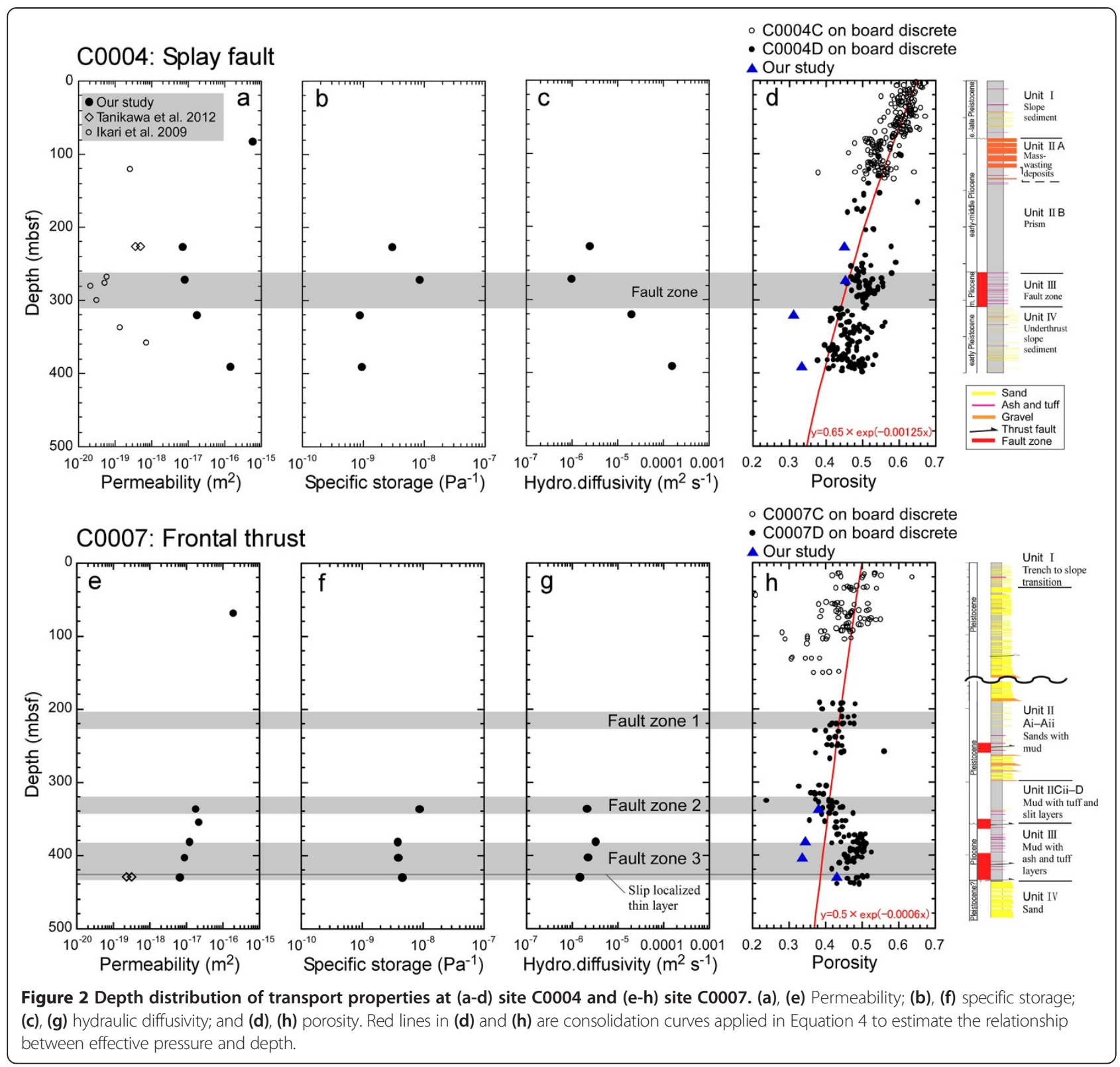

of the sample, $\eta$ is the dynamic viscosity of water, $L$ is the sample length, and $P_{\text {up }}$ and $P_{\text {down }}$ are pore fluid pressures at the upstream (the bottom of the specimen) and downstream ends (top) of the specimen, respectively. We used a pressure regulator to keep $P_{\text {up }}$ constant $(0.20$ to $1.2 \mathrm{MPa}$ in absolute pressure). The rate of water outflow per unit time from the downstream end of the samples was measured with a digital balance. We assumed a constant value of $0.1 \mathrm{MPa}$ for $P_{\text {down }}$ because the water flowing out of the lower end of the specimen was released to atmospheric pressure.

Porosity changes in response to confining pressure changes were determined by the gas expansion method (Scheidegger 1974; Wibberley and Shimamoto 2005). In this method, the pore volume change of the saturation gas (nitrogen gas was used in our tests) in a dry sample in response to the change in confining pressure is measured, and porosity is calculated by using the BoyleMariotte equation for an isothermal gas. Specific storage, $S$ s, was calculated from the porosity and the compressibility of fluid by using the following equation (Wibberley 2002):

$$
S s=\beta_{\Phi}+\Phi \beta_{f}
$$

where $\beta_{\Phi}$ is the drained compressibility, $\beta_{\mathrm{f}}$ is the compressibility of the pore fluid, and $\Phi$ is the porosity. Equation 2 is based on the assumption that the rock grains 
Table 1 Locations and transport properties of the core samples used for the laboratory experiments

\begin{tabular}{|c|c|c|c|c|c|c|c|c|c|}
\hline $\begin{array}{l}\text { Sample } \\
\text { number }\end{array}$ & Section & Lithology & $\begin{array}{c}\text { Core } \\
\text { depth below } \\
\text { seafloor }(m)\end{array}$ & $\begin{array}{c}\text { In situ } \\
\text { effective } \\
\text { pressure (MPa) }\end{array}$ & $\begin{array}{l}\text { Matrix density } \\
\left(\mathrm{g} / \mathrm{cm}^{3}\right)\end{array}$ & Permeability $\left(\mathrm{m}^{2}\right)$ & Porosity & Porosity-permeability & $\begin{array}{l}\text { Shape of } \\
\text { specimen }\end{array}$ \\
\hline C4C-1 & $\begin{array}{c}316-\mathrm{C} 0004 \mathrm{D}-10 \mathrm{H}-1,114 \\
\text { to } 116 \mathrm{~cm}\end{array}$ & Mudstone & 81.99 & 0.51 & - & $1.80 \times 10^{-16} \times\left(10^{-6} \mathrm{Pe}\right)^{-1.58}$ & - & - & Cylinder \\
\hline C4D-1 & $\begin{array}{c}316-C 0004 \mathrm{D}-19 \mathrm{R}-1,75 \\
\text { to } 77 \mathrm{~cm}\end{array}$ & $\begin{array}{l}\text { Fault } \\
\text { breccia }\end{array}$ & 226.26 & 1.59 & 2.66 & $1.24 \times 10^{-17} \times\left(10^{-6} \mathrm{Pe}\right)^{-1.25}$ & $0.452 \times \exp \left(-3.30 \times 10^{-9} \mathrm{Pe}\right)$ & $k=497.51 \times \Phi^{57.4}$ & Cylinder \\
\hline$C 4 D-2$ & $\begin{array}{c}316-C 0004 \mathrm{D}-28 \mathrm{R}-2,33 \\
\text { to } 38 \mathrm{~cm}\end{array}$ & Mudstone & 271.27 & 1.97 & 2.71 & $8.40 \times 10^{-18}-3.89 \times 10^{-25} \mathrm{Pe}$ & 0.454 to $0.00956 \times \log (\mathrm{Pe})$ & - & Cuboid \\
\hline$C 4 D-3$ & $\begin{array}{c}\text { 316-C0004D-39R-1, } 71 \\
\text { to } 73 \mathrm{~cm}\end{array}$ & Mudstone & 319.72 & 2.40 & 2.62 & $5.81 \times 10^{-17} \times\left(10^{-6} \mathrm{Pe}\right)^{-1.26}$ & $0.312 \times \exp \left(-1.64 \times 10^{-9} \mathrm{Pe}\right)$ & $k=43,340 \times \Phi^{42.7}$ & Cylinder \\
\hline C4D-4 & $\begin{array}{c}\text { 316-C0004D-54R-3, } 68 \\
\text { to } 70 \mathrm{~cm}\end{array}$ & Mudstone & 390.00 & 3.06 & 2.62 & $7.22 \times 10^{-16} \times\left(10^{-6} \mathrm{Pe}\right)^{-1.56}$ & $0.334 \times \exp \left(-1.59 \times 10^{-9} \mathrm{Pe}\right)$ & $k=1.38 \times 10^{13} \times \Phi^{60.9}$ & Cylinder \\
\hline$C 7 C-1$ & $\begin{array}{c}316-C 0007 C-7 X-5,77 \\
\text { to } 79 \mathrm{~cm}\end{array}$ & Mudstone & 67.09 & 0.55 & - & $9.17 \times 10^{-17} \times\left(10^{-6} \mathrm{Pe}\right)^{-1.19}$ & - & - & Cylinder \\
\hline C7D-1 & $\begin{array}{c}316-C 0007 \mathrm{D}-18 \mathrm{R}-3,80 \\
\text { to } 83 \mathrm{~cm}\end{array}$ & Mudstone & 335.64 & 2.97 & 2.70 & $4.13 \times 10^{-17} \times \exp \left(-0.290 \times 10^{-6} \mathrm{Pe}\right)$ & 0.483 to $0.0158 \times \log (\mathrm{Pe})$ & $k=9.9 \times 10^{13} \times \Phi^{85.4}$ & Cuboid \\
\hline C7D-2 & $\begin{array}{c}316-C 0007 \mathrm{D}-20 \mathrm{R}-2,85 \\
\text { to } 87 \mathrm{~cm}\end{array}$ & Mudstone & 353.28 & 3.14 & 2.60 & $9.87 \times 10^{-17} \times\left(10^{-6} \mathrm{Pe}\right)^{-1.36}$ & - & - & Cuboid \\
\hline C7D-3 & $\begin{array}{c}\text { 316-C0007D-23R-1, } 80 \\
\text { to } 84 \mathrm{~cm}\end{array}$ & Mudstone & 380.32 & 3.40 & 2.70 & $4.87 \times 10^{-17} \times\left(10^{-6} \mathrm{Pe}\right)^{-1.15}$ & 0.397 to $0.00799 \times \log (\mathrm{Pe})$ & - & Cuboid \\
\hline C7D-4 & $\begin{array}{c}\text { 316-C0007D-25R-3, } 110 \\
\text { to } 112 \mathrm{~cm}\end{array}$ & Mudstone & 402.48 & 3.62 & 2.63 & $3.76 \times 10^{-17} \times\left(10^{-6} \mathrm{Pe}\right)^{-1.16}$ & 0.393 to $0.00897 \times \log (\mathrm{Pe})$ & $k=2.6 \times 10^{38} \times \Phi^{117}$ & Cuboid \\
\hline C7D-5 & $\begin{array}{c}\text { 316-C0007D-28R-2, } 111 \\
\text { to } 114 \mathrm{~cm}\end{array}$ & Mudstone & 429.54 & 3.88 & 2.68 & $3.10 \times 10^{-17} \times\left(10^{-6} \mathrm{Pe}\right)^{-1.17}$ & 0.493 to $0.00950 \times \log (\mathrm{Pe})$ & - & Cuboid \\
\hline
\end{tabular}

Locations and transport properties were determined by laboratory tests, which were described as functions of effective pressure. Pe is the effective pressure $(\mathrm{Pa}), k$ is the permeability $\left(\mathrm{m}^{2}\right)$, and $\Phi$ is the porosity (no units). Equations in the list were evaluated from compression data. 
are much less compressible than the pore spaces (e.g., compressibility of mica is $1.2 \times 10^{-11} \mathrm{~Pa}^{-1}$, independent of pressure; Birch (1966)). The drained pore compressibility in Equation 2 is expressed as

$$
\beta_{\Phi}=-\left.\frac{1}{V_{p}} \frac{\partial V_{p}}{\partial P c}\right|_{P=0}=-\left.\frac{1}{1-\Phi} \frac{\partial \Phi}{\partial P c}\right|_{P=0},
$$

where $V_{\mathrm{p}}$ is the pore volume, $P c$ is the confining pressure, and $P$ is the pore pressure. Our experimental conditions mostly satisfied the conditions for which Equation 3 is valid because the pore pressure change was very small compared to the confining pressure change. Therefore, to determine specific storage, we calculated the drained pore compressibility with Equation 3 using the results of the porosity measurements (Wibberley and Shimamoto 2005). Fluid compressibility in Equation 2 was assumed to be constant at $4.3 \times 10^{-10} \mathrm{~Pa}^{-1}$ (Fine and Millero 1973). Permeability and porosity were measured at each step as confining pressure was increased in steps from 1 to 40 $\mathrm{MPa}$, and the duration before starting the permeability tests after changing the confining pressure was about 5 to $10 \mathrm{~min}$.

\section{Results}

Typical permeability and porosity behaviors in the cyclic effective pressure tests are shown in Figure 3. Both permeability and porosity decreased with increasing effective pressure, and the rate of decrease in permeability slowed as effective pressure increased. Permeability did not change very much during decompression, and it did not recover its initial value even at the lowest effective pressure. This result suggests that, in terms of permeability, the specimens showed elastic-plastic behavior in that permeability was influenced by the effective pressure history of the specimen. The porosity-pressure curve showed elastic-plastic behavior of the specimens as well, similar to the permeability (Figure $3 \mathrm{~b}$ ), but the recovery rate of porosity during decompression was faster than that of permeability. Such elastic-plastic behavior is generally observed in soft clays and soil materials (Wood 2002).

Initial permeabilities of the core samples at the lowest effective pressure (about $1 \mathrm{MPa}$ ) ranged from $3 \times 10^{-16}$ to $2 \times 10^{-17} \mathrm{~m}^{2}$, and in almost all samples, permeabilities decreased by two orders of magnitude at $40 \mathrm{MPa}$ of effective pressure (Figure 4a). The rate of reduction of permeability was similar in all samples. Mudstone from 390.00 mbsf in C0004D showed the largest permeability (C4D-4, $2 \times 10^{-17} \mathrm{~m}^{2}$ at $10 \mathrm{MPa}$ of effective pressure) among the tested samples, and fault breccia from $226.26 \mathrm{mbsf}$ in C0004D showed the smallest $\left(\mathrm{C} 4 \mathrm{D}-1,9 \times 10^{-19} \mathrm{~m}^{2}\right.$ at $10 \mathrm{MPa}$ ). The permeability curves of most samples during pressurization could be represented by the power function $k_{w}=a \cdot \mathrm{Pe}^{b}$, which is a model that was introduced by Gale (1982), or the exponential function $k_{w}=a \cdot \exp (-B \cdot \mathrm{Pe})$, where $k_{w}$ is the permeability, $a$ and $b$ are constants, and Pe is the effective pressure (Table 1 ).

The initial porosity of the specimens at the lowest effective pressure varied considerably between $31 \%$ and $45 \%$ (Figure $4 \mathrm{~b}$ ). Porosity declined by $2.5 \%$ to $3.7 \%$ at 40 MPa from the initial porosity. The largest reduction in porosity was found in the fault breccia in core sample C4D-1. Logarithmic $\left(k_{w}=a-b \cdot \log (\mathrm{Pe})\right)$ or exponential functions fitted the porosity-effective pressure curves well (Table 1).

Initial specific storage values were between $3 \times 10^{-9}$ and $1 \times 10^{-9} \mathrm{~Pa}^{-1}$, and these decreased with increasing effective pressure (Figure 4c). A rapid reduction of specific storage was observed by $10 \mathrm{MPa}$ of effective pressure, after which it increased again in several samples.

The vertical distributions of fluid transport properties at sites C0004 and $\mathrm{C0007}$ were estimated from our

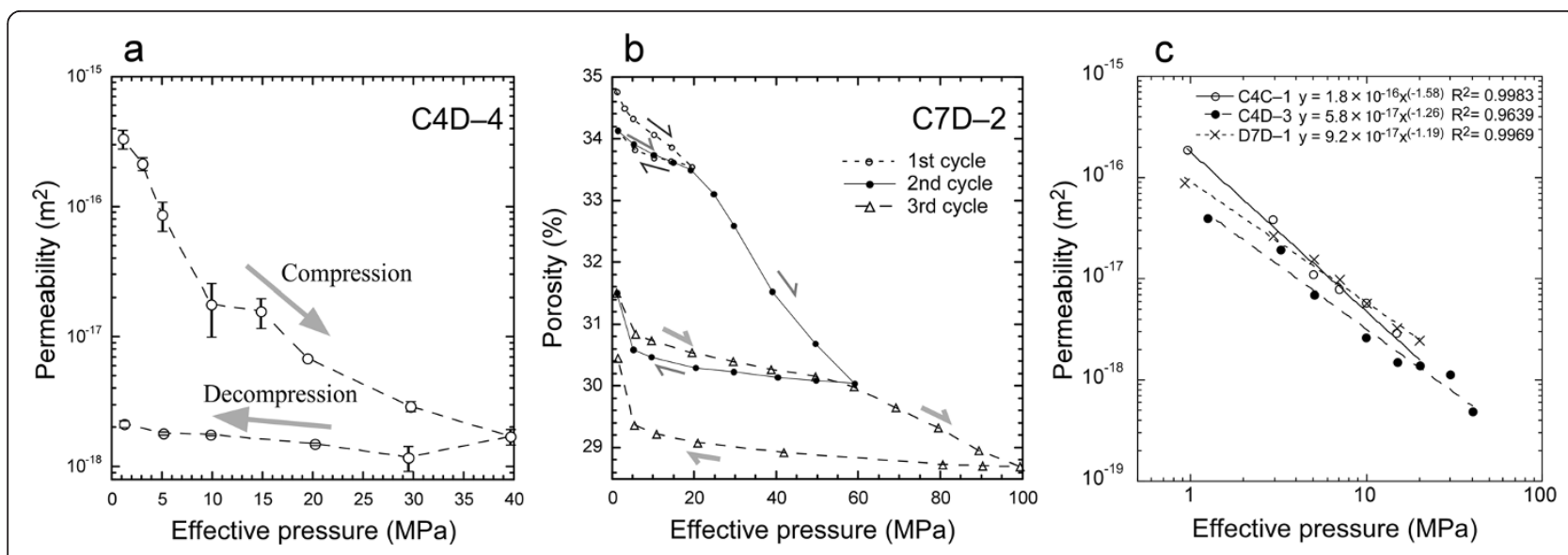

Figure 3 Examples of cyclic effective pressure tests of (a) permeability and (b) porosity. (c) Examples of fitting curves of effective pressure versus permeability for the experimental results. $R^{2}$ is the correlation coefficient. Data from compression curves (show in Figure 3a) were plotted. 

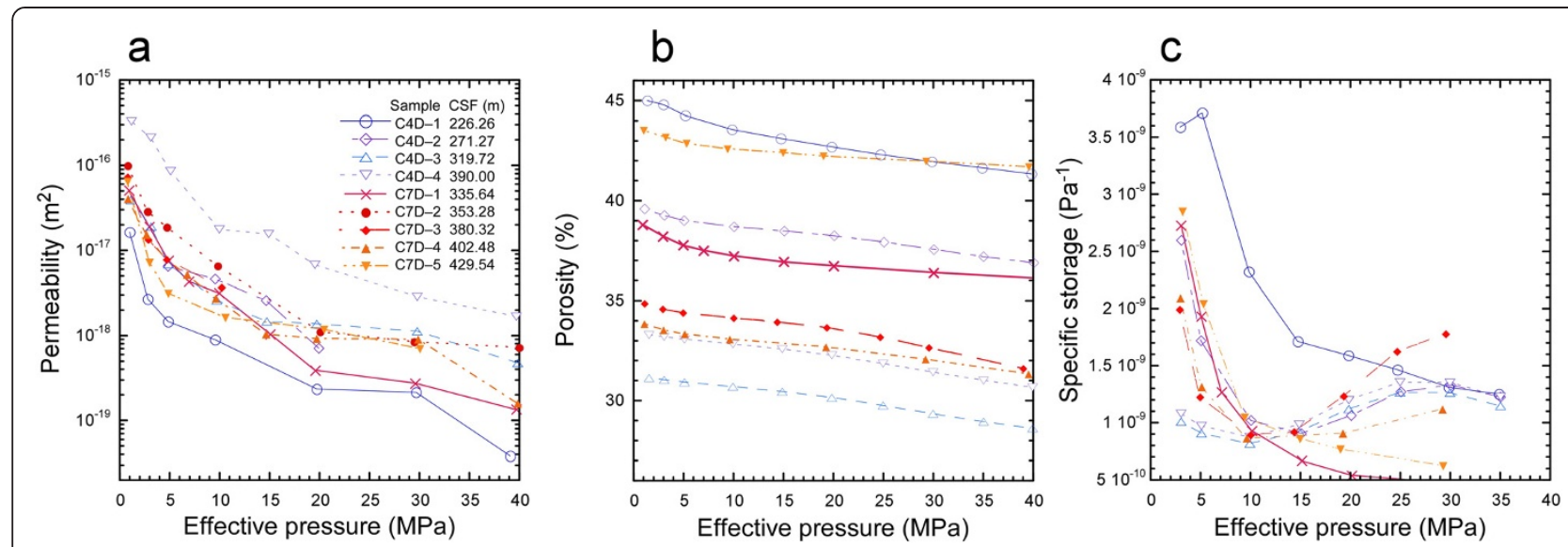

Figure 4 Permeability (a), porosity (b), and specific storage (c) as a function of effective pressure. Specific storage was determined from the porosity data shown in Figure $3 \mathrm{~b}$ by using Equations 2 and 3. Laboratory data from compression curves were plotted. CSF is the core depth below seafloor $(m)$.

laboratory results (Figure 2). Transport properties corresponding to the effective pressure at sites $\mathrm{C0004}$ and C0007 at the depth of each sample were selected and plotted. The vertical effective pressure in relation to depth below the seafloor is defined as (Wangen 1997),

$$
P e=\int_{0}^{z}\left[(1-\Phi) \rho_{r}+\Phi \rho_{f}\right] g \Delta z-\int_{0}^{z} \rho_{f} g \Delta z,
$$

which is the vertical bulk pressure minus the fluid pressure, described in terms of porosity, rock matrix density $\rho_{\mathrm{r}}$ fluid density $\rho_{\mathrm{f}}$, and gravity $g$. The depth-porosity relationship used in Equation 4 is described empirically by Athy's law (Athy 1930),

$$
\Phi=\Phi_{0} \exp (-\alpha z)
$$

where $\Phi_{0}$ is the initial porosity at $0 \operatorname{mbsf}(z=0)$ and $\alpha$ is the compaction constant.

Equation 5 fitted the porosity-depth data at site C0004 well, which were measured on board using discrete samples and a helium gas pycnometer (Figure 2d; Kimura et al. 2008) where the parameter values $\Phi_{0}=65 \%$ and $\alpha=0.00125$ were chosen. We selected $\Phi_{0}=50 \%$ and $\alpha=0.0006$ to reproduce the porosity-depth curve at site $\mathrm{C} 0007$ in an approximate manner (Figure 2h). We assumed constant $\rho_{\mathrm{r}}=2,650 \mathrm{~kg} \mathrm{~m}^{-3}$ and constant $\rho_{\mathrm{f}}=1,000 \mathrm{~kg} \mathrm{~m}^{-3}$ in Equation 4. In hole C0004D below 200 mbsf, the permeability seemed to increase a little with depth, and permeability in the fault zone was $7.6 \times 10^{-18} \mathrm{~m}^{2}$ (Figure 2a). In situ specific storage was calculated from the porosityeffective pressure curve in our laboratory tests. Hydraulic diffusivity, which was calculated as $k_{w} / \eta S \mathrm{~s}$ and equaled $9.3 \times 10^{-7} \mathrm{~m}^{2} \mathrm{~s}^{-1}$ in the fault zone, displayed the lowest value in C0004D (Figure 2c). The relative change in permeability in C0004D is similar to the permeability trend reported by Ikari et al. (2009) using core samples, although our permeability values are two orders of magnitude larger than theirs. In hole C0007D, the permeability and hydraulic diffusivity slowly decreased with depth (Figure 2e,g). Permeability and hydraulic diffusivity were both lowest at $429.54 \mathrm{~m}$ in fault zone 3 , which is very near to the depth of the slip localization layer.

\section{Discussion and summary}

Permeability and hydraulic diffusivity were lower in the shallow megasplay fault zone than in the frontal thrust fault zone $3\left(8.7 \times 10^{-18} \mathrm{~m}^{2}\right)$, but the difference was very small. Hydraulic diffusivity in both fault zones was around $10^{-6} \mathrm{~m}^{2} \mathrm{~s}^{-1}$; this value might be small enough to cause thermal pressurization (Mizoguchi et al. 2007), which is a dynamic fault-weakening mechanism. However, transport properties will evolve by rapid shear deformation, which can drastically change the permeability of fault rocks (Tanikawa et al. 2010). Tanikawa et al. (2012) performed shear-induced permeability tests at a high-velocity condition on simulated fault gouge samples from core materials taken from the megathrust fault and the frontal thrust. Permeability values in both gouges were reduced by about an order of magnitude after the friction test. Therefore, shear-induced changes in transport properties must facilitate dynamic fault weakening induced by thermal pressurization. Ikari et al. (2009) measured the permeability of simulated gouges after shearing using a true triaxial testing machine. The gouge sample was made from the core blocks that were disaggregated and sieved to small grains. Therefore, the large difference between our permeability data and that of Ikari et al. (2009) can probably be explained by the shear-induced compaction of gouge samples and by the relative smaller permeability for disaggregated gouge samples than that of intact samples (Tanikawa et al. 2012). 
Permeability at site C0007 decreased with depth (Figure 2e), although the permeability variation is quite small if permeability is plotted at the same effective pressure of $5 \mathrm{MPa}$ (Figure 5). This suggests that permeability reduction with depth is mainly explained by mechanical compaction with an increase in the effective pressure. Permeability variations at site C0004 and at site C0019 of The Japan Trench Fast Drilling Project (JFAST, IODP Expedition 343/343 T) (Tanikawa et al. 2013) are larger than that at site $\mathrm{C} 0007$. The permeability variations observed in the JFAST sites were explained by the proportion of clay minerals, whereby the higher abundance of clay in the plate boundary fault materials resulted in extremely low permeability. Therefore, permeability variation in C0004 may be explained by such variation in the mineral composition, although we need to analyze the mineral compositions in the samples to confirm our interpretation.

We did not measure the permeability of fault rock at the Nankai Trough subduction zone because of the rarity of samples. As total clay contents and smectite content in the Nankai frontal thrust are lower than those in the Japan Trench plate boundary fault (Ujiie et al. 2013), we expect that the permeability of the Nankai Trough faults is larger than that of the Japan Trench. The lower friction coefficient in the Japan Trench décollement material than that in the material from the Nankai Trough (Ujiie et al. 2013) will be probably explained by the difference in permeability, as well as in the proportion of weak clay minerals.

Sample size probably influences the permeability as well. A number of reports show the permeability for very

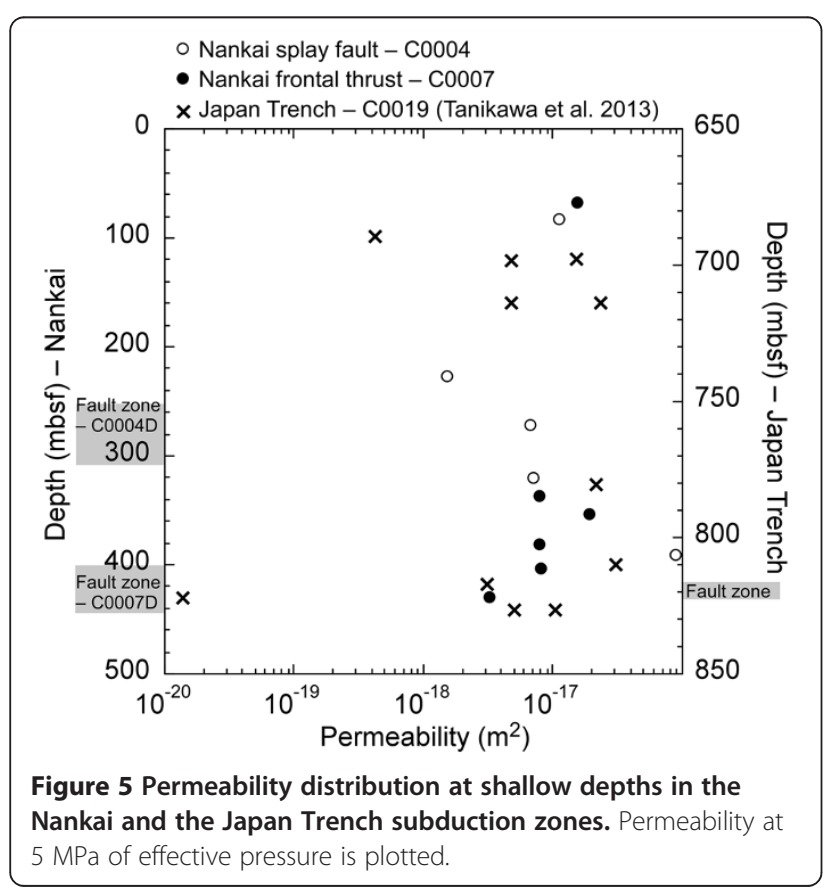

small samples with thicknesses from 0.5 to $20 \mathrm{~mm}$ (Lenormand and Fonta 2007; Lenormand et al. 2010), and we used similar small samples for the transport property measurements. However, our results suggest that permeability is independent of sample length and shape (see Additional file 1). Ma and Morrow (1996) reported that several effects of sample size on permeability will be avoided if the sample length is greater than 10 grain particle diameters; our sample size was large enough to satisfy this condition.

Hydraulic diffusivity was also lower in the Nankai megasplay fault zone than that in the surrounding host rock samples, which suggests that the fault zone can act as a barrier to fluid flow so that tectonic loading and fluid influx from the deep crust might cause the pore pressure to become relatively elevated within the fault zone. However, the difference in permeability between the fault zone and the host rocks of the frontal thrust was very small. We measured the transport properties of mudstone and fault breccia of mudstone origin, but the transport properties of sandstone and ash layers, which were observed throughout site C0007, were not measured. These rocks probably are permeable. In addition, the fracture permeability and its scaling effect on fluid transport properties have not been investigated yet. Therefore, we are not certain whether fluid flows preferentially within the fault zone in the frontal thrust region or whether it functions as a barrier. Variation in the fluid transport properties of a fault zone causes heterogeneity in the pore pressure distribution and fault strength, which influence future

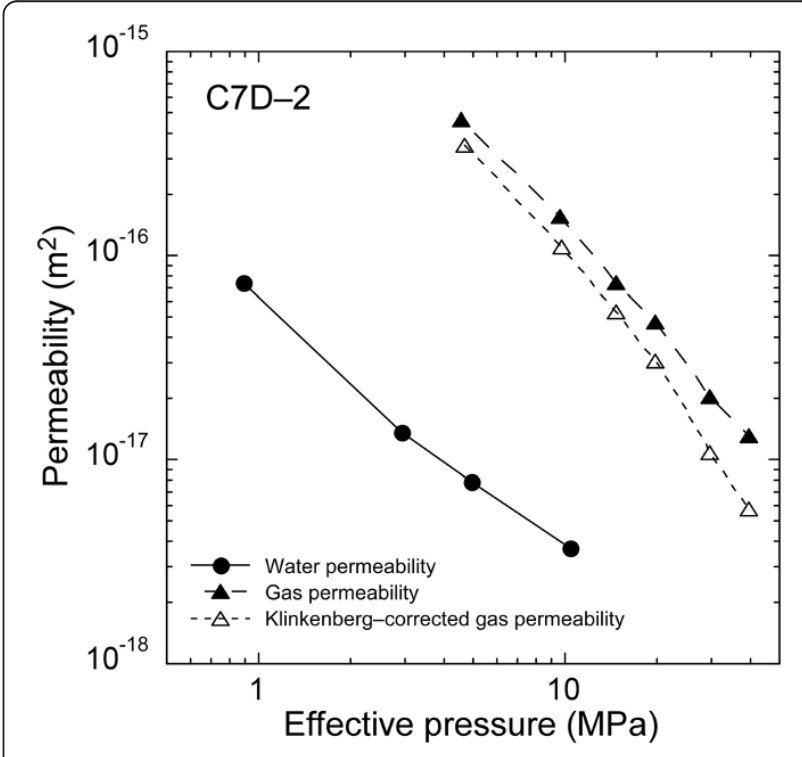

Figure 6 Permeability curves for the core sample from C7D-2. Comparison of water permeability, gas permeability estimated by using the Klinkenberg equation, and gas permeability. 
fault rupture paths in a fault system such as the Nankai branching fault system.

The reduction rates of porosity in Nankai sediments (2.5\% to $4 \%$ at $40 \mathrm{MPa}$ from the initial porosity) seem quite small compared to those in Japan Trench sediments (9\% to 15\%; Tanikawa et al. 2013), even though the reduction rates of permeability between the two sites were similar. The porosity tests in this study were performed under dry conditions, although the porosity of sediments in the Japan Trench was measured under water-saturated conditions. Wetting may enhance consolidation of sediment by mechanical collapse and grain rearrangement; this is because the shear strength of sediment particles is generally weaker when wet than when dry. Permeability measured by using nitrogen gas as a pore fluid was larger than water permeability by more than one order of magnitude (Figure 6). The difference between gas permeability and water permeability was not explained by the Klinkenberg effect (Figure 6; e.g., Tanikawa and Shimamoto 2009), even though pore pressure dependence on the gas permeability, which is known as the Klinkenberg effect, was clearly observed in our gas permeability tests. The difference was probably caused by the wetting-enhanced compaction. Therefore, we might have overestimated porosity (or underestimated the porosity reduction) and specific storage. Permeability against porosity can be plotted by combining independent permeability tests with porosity tests for specimens from the same core block. The relationship was expressed by the power law function (Table 1), although the power law exponent was extremely larger than that in previous studies (e.g., exponent $=3$ for the cubic law). This unrealistic relationship might have caused an overestimation of the porosity.

\section{Additional file}

Additional file 1: Correlation between permeability and sample length from sites $\mathbf{C 0 0 0 4}$ and $\mathbf{C 0 0 7}$. Correlation between permeability at $5 \mathrm{MPa}$ effective pressure and the sample length for different shapes of samples from the two sites in the Nankai subduction zone.

\section{Competing interests}

The authors declare that they have no competing interests.

\section{Authors' contributions}

WT contributed to data collection, interpretation, and manuscript preparation. HM carried out the laboratory tests. WL, TH, and AT contributed to sampling from IODP core samples. All authors read and approved the final manuscript.

\section{Acknowledgements}

This research used core samples provided by the Integrated Ocean Drilling Program (IODP). The authors gratefully acknowledge support provided by the DN Chikyu drilling crew and staff. This study was supported by two grants from the Japan Society for the Promotion of Science (JSPS) Grant-in-Aid for Science Research program (Nos. 25800284 and 21107004). We also thank the guest and chief editors and two anonymous reviewers for improving our paper.

\section{Author details}

'Kochi Institute for Core Sample Research, Japan Agency for Marine-Earth Science and Technology, Nankoku 783-8502, Japan. ${ }^{2}$ Marine Works Japan Ltd., Nankoku 783-8502, Japan. ${ }^{3}$ Department of Geoscience, Interdisciplinary Graduate School of Science and Engineering, Shimane University, Matsue 690-8504, Japan. ${ }^{4}$ Division of Earth and Planetary Sciences, Graduate School of Science, Kyoto University, Kyoto 606-8502, Japan.

Received: 25 February 2014 Accepted: 6 August 2014

Published: 13 August 2014

\section{References}

Andrews DJ (2002) A fault constitutive relation accounting for thermal pressurization of pore fluid. J Geophys Res Solid Earth 107:2363, doi:10.1029/2002JB001942

Athy LF (1930) Density, porosity, and compaction of sedimentary rocks. AAPG Bull 14:1-24

Bernabe Y (1987) A wide range permeameter for use in rock physics. Int J Rock Mech Min Sci Geomech Abstr 24:309-315, doi:10.1016/0148-9062(87)90867-9

Birch F (1966) Compressibility, elastic constants. In: Clark SP (ed) Handbook of physical constants-Geol Soc Am Mem 97. Geological Society of America, New York, pp 97-173

Fine RA, Millero FJ (1973) Compressibility of water as a function of temperature and pressure. J Chem Phys 59:5529-5536, doi:10.1063/1.1679903

Gale JE (1982) The effects of fracture type (induced vs. natural) on the stressfracture closure-fracture permeability relationships. In: Goodman RE, Heuze FE (eds) Proceedings of the 23rd U.S. Rock Mechanics Symposium, Berkeley, California, 25-27 August 1982. Society of Mining Engineers of AIME, New York, 290-298.

Ikari MJ, Saffer DM, Marone C (2009) Frictional and hydrologic properties of a major splay fault system, Nankai subduction zone. Geophys Res Lett 36, L20313, doi:10.1029/2009GL040009

Ito Y, Obara K (2006) Dynamic deformation of the accretionary prism excites very low frequency earthquakes. Geophys Res Lett 33, L02311, doi:10.1029/2005GL025270

Kame N, Rice JR, Dmowska R (2003) Effects of prestress state and rupture velocity on dynamic fault branching. J Geophys Res Solid Earth 108:2265, doi:10.1029/2002JB002189

Kikuchi M, Nakamura M, Yoshikawa K (2003) Source rupture processes of the 1944 Tonankai earthquake and the 1945 Mikawa earthquake derived from low-gain seismograms. Earth Planets Space 55(4):159-172

Kimura G, Screaton EJ, Curewitz D, Expedition 316 Scientists (2008) NanTroSEIZE Stage 1A: NanTroSEIZE shallow megasplay and frontal thrusts. IODP Prel Rept 316, doi:10.2204/iodp.pr.316.2008

Kimura G, Hina S, Hamada Y, Kameda J, Tsuji T, Kinoshita M, Yamaguchi A (2012) Runaway slip to the trench due to rupture of highly pressurized megathrust beneath the middle trench slope: the tsunamigenesis of the 2011 Tohoku earthquake off the east coast of northern Japan. Earth Planet Sci Lett 339-340:32-45, doi:10.1016/j.epsl.2012.04.002

Lachenbruch AH (1980) Frictional heating, fluid pressure, and the resistance to fault motion. J Geophys Res Solid Earth 85:6097-6112, doi:10.1029/JB085iB1 1 p06097

Lenormand R, Fonta O (2007) Advances in measuring porosity and permeability from drill cuttings. In: SPE/EAGE reservoir characterization and simulation conference. UAE, SPE 111286, Abu Dhabi

Lenormand R, Bauget F, Ringot G, Cydarex, ECEM (2010) Permeability measurement on small rock samples. In: International symposium of the Society of Core Analysts. Halifax, Nova Scotia, Canada, 4-7 October 2010.

Ma S, Morrow NR (1996) Relationships between porosity and permeability for porous rocks. In: International symposium of the Society of Core Analysts. Montpelier, France

Mitsui Y, lio Y, Fukahata Y (2012) A scenario for the generation process of the 2011 Tohoku earthquake based on dynamic rupture simulation: role of stress concentration and thermal fluid pressurization. Earth Planets Space 64(12):1177-1187

Mizoguchi K, Hirose T, Shimamoto T, Fukuyama E (2007) Reconstruction of seismic faulting by high-velocity friction experiments: an example of the 1995 Kobe earthquake. Geophys Res Lett 34, L01308, doi:10.1029/2006GL027931

Park J-O, Tsuru T, Kodaira S, Cummins PR, Kaneda Y (2002) Splay fault branching along the Nankai subduction zone. Science 297:1157-1160, doi:10.1126/science.1074111 
Park J-O, Kodaira S (2012) Seismic reflection and bathymetric evidences for the Nankai earthquake rupture across a stable segment-boundary. Earth Planets Space 64:299-303

Scheidegger AE (1974) The Physics of Flow through Porous Media, 3rd edn. University of Toronto Press, Toronto

Sibson RH (1992) Implications of fault-valve behaviour for rupture nucleation and recurrence. Tectonophysics 211:283-293, doi:10.1016/0040-1951(92)90065-E

Suzuki T, Yamashita T (2009) Dynamic modeling of slow earthquakes based on thermoporoelastic effects and inelastic generation of pores. J Geophys Res Solid Earth 114:B00A04, doi:10.1029/2008JB006042

Tanikawa W, Shimamoto T (2009) Comparison of Klinkenberg-corrected gas permeability and water permeability in sedimentary rocks. Int J Rock Mech Min Sci 46:229-238, doi:10.1016/j.jijmms.2008.03.004

Tanikawa W, Sakaguchi M, Tadai O, Hirose T (2010) Influence of fault slip rate on shear-induced permeability. J Geophys Res Solid Earth 115, B07412, doi:10.1029/2009JB007013

Tanikawa W, Mukoyoshi H, Tadai O, Hirose T, Tsutsumi A, Lin W (2012) Velocity dependence of shear-induced permeability associated with frictional behavior in fault zones of the Nankai subduction zone. J Geophys Res Solid Earth 117, B05405, doi:10.1029/2011JB008956

Tanikawa W, Hirose T, Mukoyoshi H, Tadai O, Lin W (2013) Fluid transport properties in sediments and their role in large slip near the surface of the plate boundary fault in the Japan Trench. Earth Planet Sci Lett 382:150-160, doi:10.1016/j.epsl.2013.08.052

Ujiie K, Chester FM, Fabbri O, Li C, Yamaguchi A, Su X, Kimura G, Screaton EJ, Curewitz D, Scientific Party (2008) Characteristics of the fault rocks at the shallow portion of the megasplay fault system and the frontal thrust in the Nankai accretionary prism off Kumano. Eos Trans AGU 89(53), Fall Meet Suppl, Abstract T21F-02

Ujiie K, Tanaka H, Saito T, Tsutsumi A, Mori J, Kameda J, Brodsky EE, Chester FM, Eguchi N, Toczko S, Scientists of Expedition 343 and 343 T (2013) Low coseismic shear stress on the Tohoku-oki megathrust determined from laboratory experiments. Science 342:1211-1214, doi:10.1126/science.1243485

Wangen M (1997) Two-phase oil migration in compacting sedimentary basins modelled by the finite element method. Int J Numer Anal Methods Geomech 21:91-120, doi:10.1002/(SICI)1096-9853(199702)21:2<91::AID-NAG860>3.0.CO;2-L

Wibberley CAJ (2002) Hydraulic diffusivity of fault gouge zones and implications for thermal pressurization during seismic slip. Earth Planets Space 54:1153-1171

Wibberley CAJ, Shimamoto T (2005) Earthquake slip weakening and asperities explained by thermal pressurization. Nature 436:689-692

Wood DM (2002) Soil Behaviour and Critical State Soil Mechanics. Cambridge University Press, Cambridge

Yamaguchi A, Sakaguchi A, Sakamoto T, lijima K, Kimura G, Ujiie K, Chester FM, Fabbri O, Goldsby DL, Tsutsumi A, Li C, Curewitz D (2009) Geochemical features of shallow subduction thrusts: non-destructive XRF core-imaging scanner analyses of NanTroSEIZE C0004 and C0007 fault zone slabs. Eos Trans AGU 90(52) Fall Meet Suppl, Abstract T21C-1829

Yoshida S, Kato N (2011) Pore pressure distribution along plate interface that causes a shallow asperity of the 2011 great Tohoku-oki earthquake. Geophys Res Lett 38:LO0G13, doi:10.1029/2011GL048902

doi:10.1186/1880-5981-66-90

Cite this article as: Tanikawa et al.: Pressure dependence of fluid transport properties of shallow fault systems in the Nankai subduction zone. Earth, Planets and Space 2014 66:90.

\section{Submit your manuscript to a SpringerOpen ${ }^{\odot}$ journal and benefit from:}

- Convenient online submission

- Rigorous peer review

- Immediate publication on acceptance

- Open access: articles freely available online

- High visibility within the field

- Retaining the copyright to your article

Submit your next manuscript at springeropen.com 